\title{
A Passive Tobacco Smoke Exposure System for Laboratory Animals
}

\author{
Isamu TANAKA', Sumiyo Ishimatsu', Toshiaki HigaSHI ${ }^{2}$, Takahiko KATOH ${ }^{3}$ \\ and Takashi AKIYAMA ${ }^{1}$ \\ 'Department of Environmental Health Engineering, Institute of Industrial Ecological Sciences, \\ University of Occupational and Environmental Health, Japan. Kitakyushu 807, Japan \\ ${ }^{2}$ Department of Health Policy and Management, Institute of Industrial Ecological Sciences, \\ University of Occupational and Environmental Health, Japan. Kitakyushu 807, Japan \\ ${ }^{3}$ Department of Biochemistry, School of Medicine, University of Occupational and Environmental Health, Japan. \\ Kitakyushu 807, Japan
}

Abstract: A simple passive tobacco smoke exposure system was developed for laboratory animals. The system consisted of a tobacco smoke generator and an exposure chamber. Performance testing was conducted using Fischer 344 rats. The rats were exposed to passive tobacco smoke generated by 20 cigarettes per day for 3 months. The concentration of the cigarette smoke aerosol (particle phase) in the chamber can be kept almost constant during exposure. The daily average mass concentration was $10.0 \pm 4.3 \mathrm{mg} / \mathrm{m}^{3}$ and the carbon monoxide was $79 \pm 22 \mathrm{ppm}$ during exposure.

Key words: inhalation chamber, passive tobacco smoke, smoke generator.

(Received 13 November 1989, accepted 21 December 1989)

\section{Introduction}

Many tobacco smoke generators have been used in exposure experiments using small rodents (Asano, 1979). However, these generators have no stability for long-term inhalation. The primary reason for this is that some chemical compounds in tobacco smoke are cohesive and adhesive. Such chemicals adhere to the walls along the stream of tobacco smoke and cause interruption of the smooth flow of smoke in the exposure system. To avoid this phenomenon, the smoke generator should be a simple mechanism and easy to clean when it is to be used for long-term inhalation toxicity studies. We have developed a simple tobacco smoke generator that meets these criteria. The performance of the system was tested by exposing rats to passive tobacco smoke for 3 months.

\section{Methods}

Experimental apparatus

Figure 1 illustrates the smoke generator and the exposure chamber. The chamber was of a whole-body exposure type. The chamber volume was $100 \ell$. The filtered air was introduced into the top of the chamber for dilution and the flow directed downward. 


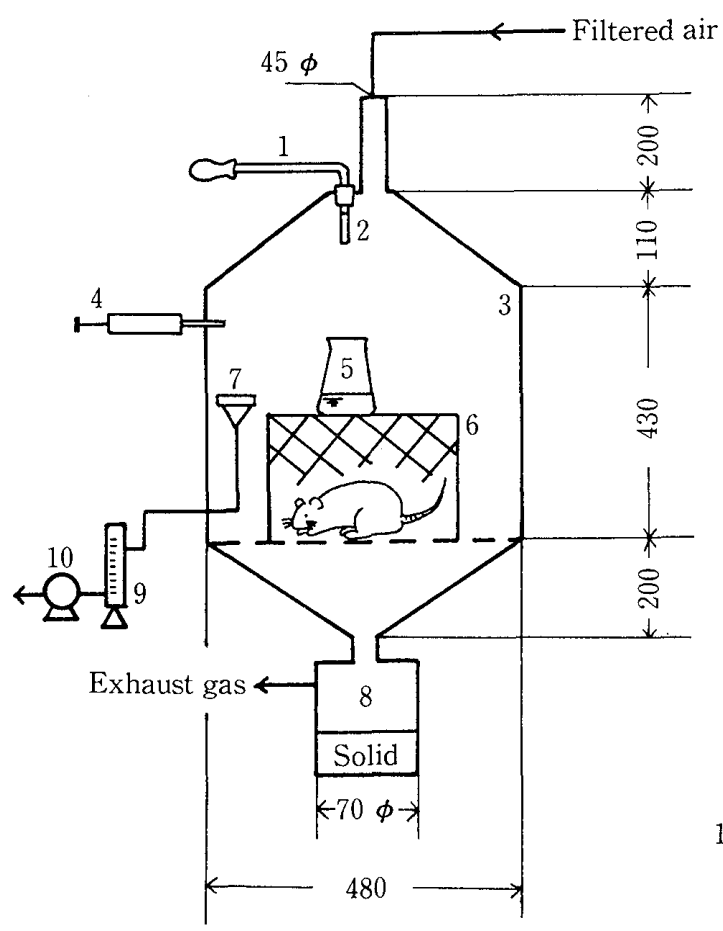

1. Tobacco smoke generator

2. Cigarette

3. Exposure chamber (Sakuragi Chem. Co. Japan)

4. CO sampler (Intermittently)

5. Conical beaker

6. Cage $(350 \times 350 \times 200 \mathrm{H})$

7. Filter sampler (A type $55 \phi$; Shibata Sci. Co. Japan)

8. Separator

9. Flow meter (Max $2.0 \mathrm{l} / \mathrm{min}$; Kojima Co. Japan)

10. Vacuum pump (AP-032; Iwaki Co. Japan)

Fig. 1. Schematic diagram of a passive tobacco smoke exposure system for laboratory animals.

The flow rate in the chamber was $50 \ell / \mathrm{min}$ (30 complete air changes per hour). The temperature and the relative humidity in the exposure chamber was kept at $25 \pm 2{ }^{\circ} \mathrm{C}$ and $50 \pm 10 \%$, respectively.

The smoke generator consisted of a glass tube with an aspirator made of rubber attached to one end for air inflow. The cigarette was inserted into the other end of the glass tube. To prevent cigarette ashes from falling on the rodents, a conical beaker was placed immediately below the cigarette as shown in Fig. 1.

The mass concentration of the passive tobacco smoke aerosol during exposure was determined by using glass fiber filter samples. The grab concentration of carbon monoxide in the chamber was measured by a direct reading gas detector tube (Kitagawa Co. Japan).

\section{Experimental procedure}

After lighting the cigarette manually, the smoke generator was immediately inserted through the top of the exposure chamber. As the cigarette burned, the smoke descended slowly with the air flow and exited from the bottom of the chamber. One cigarette produced smoke for $12 \mathrm{~min}$. After the cigarette burned down to the filter, the smoke generator was withdrawn from the chamber and a new cigarette attached. This method was performed continuously until all 20 cigarettes were used up.

\section{Cigarettes}

The cigarettes used in this experiment were purchased from the Japan Tobacco Inc. 
Japan. Their trade name is "Peace (Long Size)" and contain $2.0 \mathrm{mg}$ of nicotine and 23 mg of tar per cigarette.

Animals

The rodents used were Fischer 344 male rats (6 weeks old). The rats were randomly divided into one control (8 rats) and two test groups $(6$ and 7 rats). Each group was housed together in a stainless steel wired cage. Animals had unrestricted access to commercially available certified feed pellets (CE-2, Clea Japan Inc.) and tap water. Feed and water were not available during the inhalation exposure.

Exposure

The Fischer male rats were exposed to the passive tobacco smoke of 20 cigarettes/day ( $4 \mathrm{hr} /$ day), 5 days per week for 3 months. Immediately after each daily exposure, the smoke generator, the exposure chamber and the cage were cleaned.

\section{Results and Discussion}

Usually a burning cigarette extinguishes without a flow of air. With this experimental method, the cigarette was located near the filtered air inlet at the top of the chamber. The cigarette continues to burn due to the air passing through the filtered air inlet (superficial velocity: $17 \mathrm{~cm} / \mathrm{sec}$ ).

All the parts in the exposure system that came into contact with the tobacco smoke after daily exposure were cleaned for $1 \mathrm{hr}$. This cleaning is one of the most important factors to keep the mass concentration of the smoke constant in the chamber over a long period of time. All parts of the exposure system were designed for easy cleaning. The experimental conditions are summarized in Table 1.

The daily mean $\pm \mathrm{SD}$ mass concentrations in the chamber was $10.0 \pm 4.3 \mathrm{mg} / \mathrm{m}^{3}$ as

Table 1. Inhalation conditions

\begin{tabular}{ll}
\hline Test aerosol & $:$ Passive tobacco smoke \\
Test species & $:$ Fischer 344 male rats \\
Number of rats per group & $: 6$ and $7 \mathrm{rats}$ \\
Exposure time & $: 360 \mathrm{hr}$ \\
& $(4 \mathrm{hr} / \mathrm{d}, 5 \mathrm{~d} / \mathrm{wk}$, for $3 \mathrm{mo})$ \\
& $:(20 \mathrm{cigarettes} / \mathrm{d}=4 \mathrm{hr} / \mathrm{d})$ \\
Concentration of cigarette smoke & $: 10.0 \pm 4.3 \mathrm{mg} / \mathrm{m}^{3}$ \\
CO concentration & $: 79 \pm 22 \mathrm{ppm}$ \\
Chamber volume & $: 100 \ell$ \\
Air flow rate & $: 50 \ell / \mathrm{min}$ \\
Temperature \& humidity in chamber & $25 \pm 2^{\circ} \mathrm{C} \mathrm{\& 50 \pm 10 \%}$ \\
\hline
\end{tabular}

The exposure system is cleaned every exposure day. 
measured from the glass fiber filter samples. There was no significant difference between the two exposure chambers used. This suggests that the smoke concentration was kept almost constant during exposure.

The size distribution of the tobacco smoke particles was not measured in this experiment. Higashi et al. (1985) reported that the count median diameter (CMD) and the geometric standard deviation (GSD) of the side stream of tobacco smoke measured by a scanning electron microscope were $0.43 \mu \mathrm{m}$ and 1.33, respectively. The relationship between mass median diameter (MMD) and count median diameter is shown in the following equation (Tanaka, 1987):

$$
\ln \mathrm{MMD}=\ln \mathrm{CMD}+3(\ln \mathrm{GSD})^{2} .
$$

The MMD is $0.55 \mu \mathrm{m}$ as calculated from the CMD of $0.43 \mu \mathrm{m}$. Chen et al. (1987) reported that the mass median aerodynamic diameter (MMAD) measured by a multi-jet impactor increased linearly from 0.40 to $0.65 \mu \mathrm{m}$ in a concentration range of $100-800$ $\mathrm{mg} / \mathrm{m}^{3}$. These reports indicate that passive tobacco smoke contains respirable particles.

The concentration of carbon monoxide $(\mathrm{CO})$ in the chamber was $79 \pm 22 \mathrm{ppm}$ measured by the direct reading gas detector tube. Chen et al. (1987) showed that the relationship between the $\mathrm{CO}$ concentration and the mass concentration (MASS) is as follows:

$$
\mathrm{CO}(\mathrm{ppm})=0.52 \operatorname{MASS}\left(\mathrm{mg} / \mathrm{m}^{3}\right)+16.9 ; \quad 100<\operatorname{MASS}<800 \mathrm{mg} / \mathrm{m}^{3}
$$

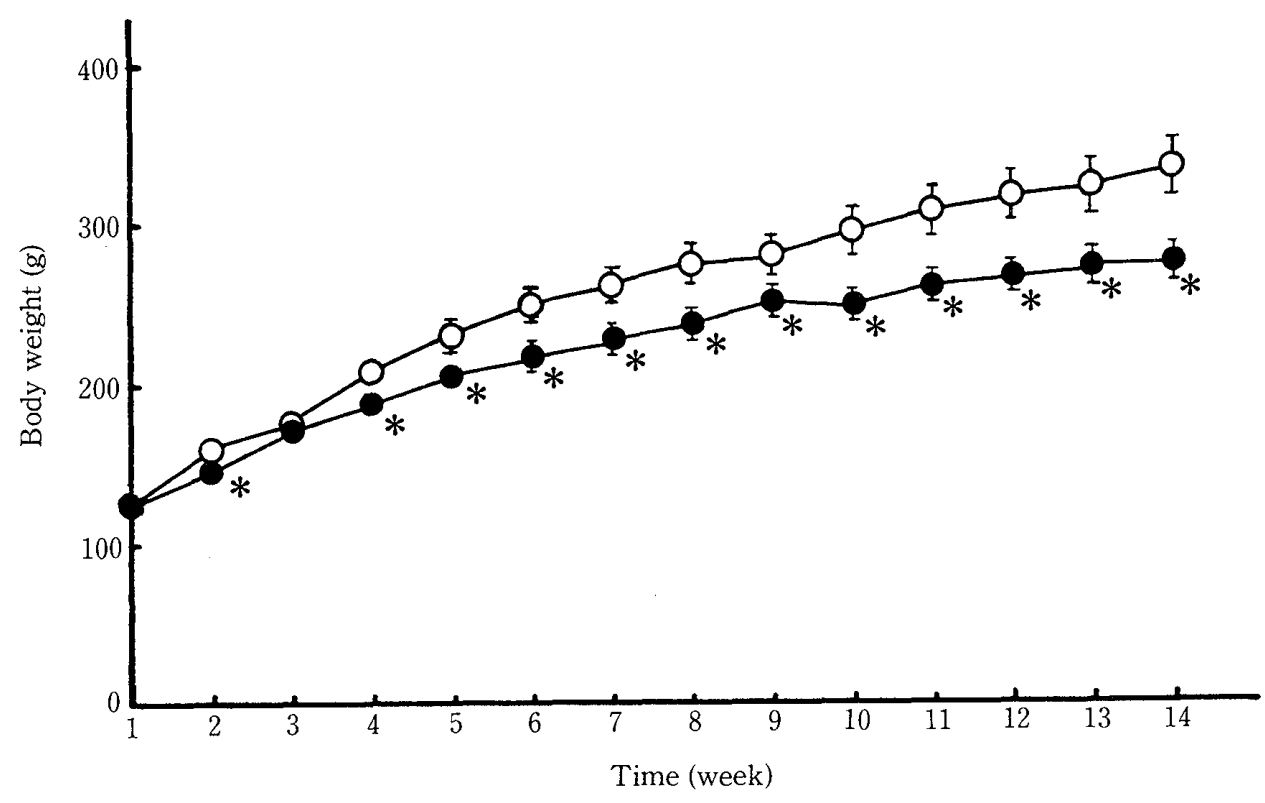

Fig. 2. Comparison of growth (body weight) between tobacco smoke exposed and control rats. Asterisk $*$ indicates a significant difference between the exposed and control rats, $P<0.01$ by Student's t test.

- Exposure, O Control 
By substituting $10.0 \mathrm{mg} / \mathrm{m}^{3}$ from our experiment into the equation, the estimated CO concentration would become $22 \mathrm{ppm}$, that is, 5 times smaller than the values measured in our experiment. The cause of this is the difference in the conditions of burning (temperature, velocity, flow rate of the clean air, etc.).

During tobacco smoke exposure, we found that urine volume increased in the exposed group, but quantitative measurements were not made. Figure 2 shows the comparison of body weight between the exposed and control rats. There were significant differences $(P<0.01)$ in body weight between the exposed and the control groups after 4 weeks of exposure. Exposed rats had smaller weight gains than the controls.

The biochemical and histopathological changes of passive tobacco smoke exposed rats will be reported separately.

We believe the exposure system developed is valid for investigating the chronic health effects of passive inhalation of tobacco smoke.

\section{References}

Asano, M. (1979): Tobacco. In: Inhalation Experiments-It's Application to Atmospheric Pollution Research-. (Kawai, K. \& Yokoyama, E., ed.). Soft Sci. Inc., Tokyo. pp. 353-396.

Chen, B. T., Barr, E. B., Cheng, Y. S. et al. (1987): Comparison of cigarette smoke exposure atmospheres in nose-only and whole-body chambers. In: Inhalation Toxicology Research Institute Annual Report. (McClellan, R. O. et al., ed.). National Technical Information Service, Springfield, VA. pp. 68-71.

Higashi, T., Sakurai, H., Toyama, T. et al. (1985): Fixation method of tobacco smoke aerosols and aerodynamics in the respiratory tract. Jap. J. Publ. Hlth., 32: 17-23.

Tanaka, I. (1987): Particle size distribution in lungs and bronchopulmonary lymph nodes due to long-term exposure to coal fly ash aerosol in rats. J. UOEH, 9: 361-367. 


\section{タバコ副流煙吸入暴露装置の試作}

田中 勇武 ${ }^{1}$ 石松 維世 $^{-1} \cdot$ 東 敏昭 ${ }^{2}$ 加藤 貴彦 $^{3} \cdot$ 秋山 高 $^{1}$

1栍業医科大学产業生態科学研究所労衝衛生工学教室

2產業医科大学産業生態科学研究所產業保健管理学教室

産業医科大学生化学教室

要旨： タバコ受動喫煙による生体影響を調べるための小動物用吸入暴露装置を試作し，その性能 をFischer 344 雄性ラットを用いてテストした。試作された装置は，タバコ副流煙発生装 置と吸入暴露チャンバーとから構成されている，性能テストのための吸入暴露条件は 1 日 20 本 (4 時間)，1 週 5 日で 3 カ月間行われた。この間の日平均粒子濃度は $10.0 \pm 4.3$ $\mathrm{mg} / \mathrm{m}^{3}$ ，一酸化炭素濃度は $79 \pm 22 \mathrm{ppm}$ であった。暴露期間中ほぼ一定の濃度を保って暴 露できることが確認されたことから，試作された本装置は，タバコ受動喫煙による生体影 響を調べる装置として有用であると考えられる。

J. UOEH (産業医大誌), 12 ( 1 ): 37-42 (1990) 